
Tydskrif vir Taalaanleer

\title{
CORRELATING FIRST-YEAR LAW STUDENTS' PROFILE WITH THE LANGUAGE DEMANDS OF THEIR CONTENT SUBJECTS
}

\author{
Themba Ngwenya \\ North-West University, Mafikeng campus
}

Many first-year law students experience language-related difficulties in their studies. These difficulties apply, to a large degree, to both mother tongue English students, as well as to English Second Language (ESL) students. The difficulties stem from the fact that legal English is often a difficult register. For first-year ESL law students at the North-West University (Mafikeng), the problems are even greater, English being a second and sometimes a foreign language to them. They have, because of this, to contend with decoding everyday English usage before they grapple with understanding its legal jargon. It appears that there has been very little research into who exactly first-year law students are at historically disadvantaged campuses and what the nature of their language needs is. Thus, using a questionnaire, this article profiles first-year law students at a historically disadvantaged campus of the North-West University (Mafikeng). The results are correlated to the participants' language needs identified through a proficiency test and a semi-structured interview, and on the basis of this correlation, an effective syllabus is designed.

\section{INTRODUCTION}

The language problems that first-year law students face have been discussed fairly extensively (Feak \& Reinhart, 2002; Kleyn \& Viljoen, 1995; Riley, 1994; Smuts, 2000; Van der Walt, 1992; Van der Walt \& Nienaber, 1996) but very little research has been focused on students at a historically black South African university. In a country like South Africa, where the majority of the student population consists of English second language (ESL) learners, exploring language problems like the ones the participants in the current study encounter is imperative. The general English remedial course (called Special English) that first-year students were taking at the North-West University, Mafikeng campus, was found to be not very effective mainly because most students could not transfer the skills they had been learning in the remedial course to their mainstream courses (Agar, 1990). To obviate this problem, a content-based course called English and Academic Skills (EAS) was mounted, but it has not been spelt out what exactly the content of this course is. This article examines the participants' (first-year law students') profile and correlates it to the language and skills proficiencies their mainstream courses demand in order to stipulate what exactly the syllabus content of their English remedial course should entail. 


\section{LITERATURE REVIEW}

The literature review below discusses the participants' acquisitional context, legal English, content-based instruction (CBI) and academic literacy in order to contextualise the literacy challenges first-year law students face at North-West University, Mafikeng campus.

\subsection{Acquisitional context}

Kumaravadivelu (1994:42) argues that, for ELT to be relevant, the establishment of a wide acquisitional context is imperative. According to him, acquisitional context refers to, among other factors, the educational environment in which L2 teaching and learning take place. The current South African educational system follows outcomes-based education (OBE) and as far as language teaching is concerned, OBE is founded on the use of communicative language teaching (CLT) and one of the specific outcomes the approach aims for in the FET curriculum is that 'Learners use appropriate communication strategies for specific purposes and situations'. Even though these outcomes are aimed for at the school and tertiary level, many of the participants in the current study have not attained them. The CLT method is eclectic, though. Unlike popular CLT, OBE-related CLT requires that, besides teaching students to communicate effectively, form should also be taught. Because of this, one of its languagerelated specific outcomes is that 'Learners understand, know and apply language structures and conventions in context'. Some language items are less salient than others and may go unnoticed by the learners if their attention is not drawn to them. These include grammatical elements such as modal auxiliaries, articles and derivational forms, which are usually not stressed in everyday discourse and pedagogy but are important to use correctly in academia. In legal discourse, for example, there is a world of difference between 'The accused was at church' versus 'The accused was at the church'; between 'She threw the knife at him' versus 'She threw the knife to him'; and between 'She asked who had been eating the porridge' versus 'She asked who had eaten the porridge'. Also, learners in a homogeneous group, like the participants in this study, tend to fill in for one another because of the shared knowledge they have and not demand the precision that is often required in a heterogeneous group. These areas might not be picked up if the attention is not focused on form. Furthermore, learners might not notice indirect correction like reformulation, which might be misinterpreted as an alternative way of saying the same thing (Lightbown \& Spada, 2006). Research indicates that focus on form facilitates acquisition (Ellis \& Barkhuizen, 2005; Brown, 2000; Celci-Murcia, 2001; Gass, 1997; Long, 1983, and 1996; Nunan, 2003).

Regarding punctuation in a legal text, Mellinkof (in Wydick, 1994:80) states that 'if you don't punctuate, the reader will do it for you in places you never wanted it'. Lack of punctuation or incorrect use of it might distort meaning and lead to dire consequences in law, therefore special care should be taken that it is done to communicate the intended meaning. To illustrate how failure to use a hyphen could create imprecision, in the sentence 'The new tax deduction is designed to aid small business owners', 'small business owners' could, on the one hand, refer to persons who own small businesses or it could, on the other hand, also refer to business owners who are small in size. The sentence has broken the rule that if two words act together as a single modifier of the head noun, they should be joined by a hyphen. Thus, 'small business' should be 'small-business'.

It is all very well for students to be able to communicate well and observe the conventions of grammar, spelling and punctuation, but they also need to be aware of ideology in language use. One of the critical cross-field outcomes of the South African education system is to teach 
learners the skill to '...critically evaluate information' (RNCS, 2002:11). This outcome is essential for law students such as the participants in the current study, because law students and law practitioners frequently argue cases, many of which are based on ideological differences. Students need to be aware of how language use is reflective of the speaker's/writer's ideology. For example, one's ideology might cause a language user to choose some ways of communicating over others in legal discourse. The use of the agentless passive, for instance, often conceals who the doer of the action (sometimes the culprit) is. This choice of linguistic structure might benefit the person who uses it at the expense of somebody else.

Critical language awareness has been important in outcomes-based education because it foregrounds the cultural background, language and identity of L2 students and the interrogation of the values, goals, and practices of the teaching and learning environment (cf. Hyland \& Hamp-Lyons, 2002:3). Mainstream second language learning and CLT have been criticised for marginalising the politics of language use. Foregrounding critical language awareness, Lantolf and Appell (1994) and Hall (1997) reject what they regard as the reductive cognitivism of mainstream second language acquisition (SLA) and advocate the broadening of this field to include a critical sociocultural perspective. This suggests that the teaching of writing should, for instance, not be limited to the use of the process approach which focuses on the raising of the workings of the mind as a student encodes or decodes a text and takes a knowledge of genre as a given. In reaction to this practice, the genre approach emphasises that the lecturer's task does not simply involve equipping learners with the skills of reading and writing well because such skills vary with context. Teachers, in the words of Hyland (2003:21), therefore need '...to explore ways of scaffolding conscious understanding of target genres and the ways language creates meanings in context'. Larsen-Freeman (2000:174) offers a compromise and suggests that the psycholinguistic approach should be made to complement the sociolinguistic one because no single approach is sufficient on its own.

\subsection{Legal English}

To ESL students, legal English is doubly difficult because they have to understand the code first and then the legal register. One would have thought that legal English would be as accessible as possible because one cannot plead ignorance in court, but it is far from being so; it is notorious for its turgidity. Wydick (1994:35) bemoans the frequent use in legal English of sentences that 'twist on, phrase within clause with clause, glazing the eyes and numbing the mind of ...readers'. A sentence in legal English is unusually long because it tries to incorporate all the information that it is about so that there are no loopholes.

There are also etymologies and meanings that make legal concepts unique. The term 'homicide' is derived from the Greek words homos (a human being) and cide (killing). Because of the Roman-Dutch law origins of the South African legal system, there are many Latin phrases that law students come across in their courses. Ratio decidendi and mutatis mutandis are Latin words, while in lieu and estoppel are French. To be bombarded with words of Greek, Latin, and French origin when one has not mastered the code of instruction, as in the case of the participants in the current study, tends to diminish one's confidence in handling legal English.

Danet (1985) and Mellinkoff (1963) give a long list of typical features of legal English which occur frequently in first-year law students' textbooks. Because of space constraints, I shall mention only two of these: common words with uncommon meanings and an impersonal 
style. Regarding the former, the term 'party' does not mean an occasion for eating, singing, and dancing, but one of the sides or a person in a legal agreement or dispute. 'Action' has very little to do with a process of doing something or something that one does; it refers to a lawsuit. The semantic shift in the lexis here is closely related to the high level of formality that features in legal discourse. Colloquialism or slang is usually not appropriate in academia. Where an option exists between using either an informal or a formal word, preference is often given to the formal one. Thus, 'residence' and 'modified' are preferred over 'home' and 'altered', respectively. Formality lends authority and appropriateness to formal legal discourse. As in dealing with the lexical semantic shift of common words, so frequent in discipline-specific discourse, accommodating the formal register in one's ESL repertoire adds an extra load on the shoulders of many L2 first-year students when they are still using colloquialism and slang as a scaffolding to academic discourse.

In the case of the tendency to use an impersonal style, legal English discourse has a propensity to exclude referential pronouns, particularly 'I' and 'you'. Danet (1985:283) remarks that 'Even when texts are intended as communication between two parties, they are typically cast in the third person. Bank loan forms may speak of "the borrower" and "the lender", for instance'. An impersonal style lends an illusion of objectivity to legal discourse and renders it both less transparent and less challengeable. One of the problems first-year students experience in trying to use an impersonal style in writing is that they often discard their individual critical voice and, as a consequence, rely heavily on merely stating what authorised and authoritative writers say on an issue. They, in other words, fail to strike the required balance between citing the views of their sources and expressing their own critical comments as well. Exacerbating the language problems of participants in the current study in this regard is that many of these students come from a very oral tradition and know little how to use it as a resource in a literate setting.

\subsection{Content based instruction}

Content based instruction (CBI) is a teaching method that focuses on learning about something rather than learning about language. It is based on the premise that students could acquire the target language more successfully by using it to study content subjects such as law. Instead of regarding language as an end in itself, educators in CBI view it for what it really is in the field that is being studied. Emphasis put on either language or content varies and affects the nature of the model according to which a course is developed, giving rise to a continuum which places content-driven models at the one end and language-driven models at the other end as is shown in Duenas' (2004:80) model in Figure 1 below:

Content-driven

Language-driven

\begin{tabular}{|c|c|c|c|c|c|}
\hline Total & Partial & Sheltered & Adjunct & Theme based & $\begin{array}{l}\text { Language classes } \\
\text { with frequent use }\end{array}$ \\
\hline Immersion & Immersion & Courses & Model & Courses & $\begin{array}{l}\text { of content for } \\
\text { language practice }\end{array}$ \\
\hline
\end{tabular}

Figure 1: Content-based language teaching. A continuum of content and language integration 
As Figure 1 indicates, at the end of the right-hand side of the spectrum, language-driven CBI, which pays attention to language practice, takes place now and then; and, at the other end, content-driven CBI occurs, which entails immersing a learner into a foreign language,. Between these extremes, there are various permutations of CBI. In the current study, the focus will be on the adjunct model, because that is the nature of the current remedial course being taken by the participants.

\subsubsection{The adjunct model}

Classes of adjunct content-based teaching are usually taught by language specialists. The classes are usually designed to prepare ESL students for mainstream classes and may be similar to ESP classes in which emphasis is placed on learning basic target concepts and skills. The participants' current remedial course at NWU, Mafikeng campus, has evolved from being a general course to being content-based. After realising that many students could not transfer the skills that they were being taught in the previous general English remedial course to mainstream courses and that there was a common demotivating perception among first-year students that the remedial course basically offered what they had been taught at high school, the Mafikeng campus is changing the general remedial course to make it contentbased.

\subsection{Academic literacy}

Academic literacy is not only about academic language skills such as reading and writing; it also involves ideological issues outside of general English Language Teaching (ELT). Hyland (2002:5) points out that "Academic literacy" has its basis in educational Marxism and critical linguistics/critical education and so argues from very different premises than traditional EAP [English for Academic Purposes]'. Thus, in relation to the teaching of writing through the popular writing process approach, it may call into question this practice and problematise the fact that teaching writing as a process is often skewed towards L1 students who, being immersed in the values of the cultural mainstream and often share the lecturer's familiarity with key genres, can readily infer the conventions of academia. The problem is that, as Hyland (2003:19) points out, 'In process classrooms, students are not typically given explicit teaching in the structure of target text types. Instead they are expected to discover appropriate forms in the process of writing itself...'. Academic literacy à la the genre approach holds that language use is socially situated and an index of broader sociocultural values, beliefs, attitudes, and practices (Alidou, 2003; Ball \& Freedman, 2004; Ball \& Lardner, 2005; Hyland \& Hamp-Lyons, 2002; Hyland, 2003; Winford, 2003). Thus, besides acknowledging the importance of teaching students to read and write well, because, at the end of the day, they usually pass or fail mainly on the basis of their competency in these skills in the current academia, academic literacy also raises their awareness of power relations in their environment - their classroom, and institution - in order to encourage them to effect change in the target context and not perpetuate the status quo. For instance, academic literacy in the South African context would problematise the choice of English instruction for indigenous South African students. It would argue, like Mamphele Ramphele (2009a:19, Ramphele (2009b:11) does, that the poor academic performance of second language students and high drop-out rate are 'caused by South Africa's misguided language policy'. This argument has been confirmed in The City Press (2008, June 12), which reported that Dr Theuns Eloff, the Higher Education South Africa chairperson who is also the Vice-Chancellor of the NorthWest University, in his presentation to the South African parliamentary portfolio committee on education indicated that about $35 \%$ of all first-year students - mainly black - in South 
Africa dropped out before the middle of their academic year in South African universities. Soon after his report appeared in the newspapers, Eloff remarked in a radio interview (SA FM Morning Talk, 2008) that 'the major reason for the high number of black students' drop-out was that they (the black students) learned through a second, and sometimes third language'.

Receiving education in one's mother tongue in South Africa is not a privilege but a basic human right. Section 6 of the Constitution of the Republic of South Africa Act of 1996 provides for the granting of equal status to all the eleven official languages of the country. Thus, the Language Policy for Higher Education (2002, 3.1.2) states that 'Everyone has the right to receive education in the official language or languages of their choice in public institutions...'. The United Nations Educational, Scientific and Cultural Organization (UNESCO) pointed out as long ago as in 1953 that the best teaching and learning and quality lifelong learning are achieved through mother tongue instruction. The Pan South African Language Board Act No. 59 of 1995, The OAU 1986 Language Plan of Action for Africa, and the 2000 Asmara Declaration all call for practical, robust usage of indigenous languages in Africa in all domains. Balfour (2007:11), also, advises that, where rich exposure to the L2 is insufficient, as English is in the mainly rural and impoverished North-West Province in South Africa, it is advisable to use mother tongue instruction throughout formal learning and 'tutor-enriched' English input only for the purpose of teaching English as an L2 subject. For now, however, it would seem that the best a remedial English teacher for first-year law students at the Mafikeng campus can do is to try to make English instruction as effective as possible while advocating a change to mother tongue instruction.

\section{METHODOLOGY}

The current research is mainly descriptive and qualitative. In other words, it does not involve treatment or manipulation of the participants. It uses, instead, triangulation of data. The data obtained through a questionnaire, a language proficiency test and a semi-structured group interview are correlated to the participants' learning needs in order to determine what content their (the participants') English remedial course should have for them to study successfully. The reason for choosing a multifaceted methodology like the one used in this study is that, as Denzin and Lincoln (2000:9) point out, 'No single [research] method can grasp all of the subtle variations in ongoing human experience'.

\subsection{The participants}

The study involved an existing class of 105 ESL, full-time, resident students of a historically black campus of the North-West University, Mafikeng. Sixty-one of them were male and forty-four female. Of the 105, nine participants were foreign nationals from diverse parts of Africa, 72 were first-year, first-time entrants and 24 were re-entrants. All the participants were taking a remedial English course called English and Academic Skills (EAS), compulsory to all first-years and credit-bearing at the Mafikeng campus. The course was content-based and lasted one year. It was aimed at developing mainly first-years' reading and writing skills. All the participants were following a four-year bachelor's degree in law, the Baccalaureus legume (LLB) programme. Besides taking the two-module EAS course, they were also taking two modules in computer/information skills, four modules of an existing first-year English course and seven law courses - three in the first semester and four in the second. 


\subsection{Procedure}

The study made use of convenience sampling, i.e. the selection of an existing group rather than individuals, as participants in the study. In order to ensure internal validity, the instruments used were pilot-tested and the test was graded by three assessors. The questionnaire was given to the participants who were then asked to fill it in towards the end of the second semester because it was assumed that by that time the participants would be able to give information from a more informed position. The purpose of the questionnaire was to obtain the participants' biographical information, their perceived language abilities, lacks, and expectations.

The proficiency test was administered at the beginning of the semester before any teaching had commenced and it was taken under examination conditions. Its aim was to determine the participants' level of language competency at the beginning of the year, before they received any tuition. Assessment was not done as a lecturer in the law faculty would do it; it focused on the understanding of and ability to express general concepts of human rights rather than the hard-core legal nuances of this term. The test was based on reading comprehension and an essay. Reading and writing were chosen because they were regarded as more problematic for first-years than listening and speaking (Zulu, 2005 and 2008). Each section carried fifty marks. The scores of both sections were combined to give each participant a mark out of a hundred. The first part of the test was the reading comprehension test. It was based on three short texts; one on children's rights, one on consumers' rights, and one on animals' rights. To distinguish between good and weak students, the complexity of the questions was varied. Questions of the lower-order level involved finding a direct reference, a copy, and a fact (10 marks). Higher-order level questions were about relating endophoric to exophoric information, giving one's own opinion, drawing inference, supposition, synthesis, evaluation, and critical reading (30 marks). The middle-of-the-road questions included understanding meaning in context, paraphrasing, 'true or false' questions, relating one part of a passage to another, and analysis (10 marks).

The second part of the proficiency test was based on writing a two-page argumentative essay under examination conditions; the topic was on basic human rights and required students to use any information in the comprehension test passages to structure an essay. The essays were assessed on the basis of content (20 marks), information structure (10 marks), language and vocabulary (10 marks), style (5 marks), punctuation, and spelling (5 marks). The test was graded by myself and moderated by two other assessors. All the assessors used a similar marking grid. After I had graded all the tests, each of the other assessors moderated $5 \%$ of the tests with the highest marks and the same percentage of the tests with the lowest marks, and $10 \%$ of those with the average marks. The number of the moderated tests in the average category was higher because most of the students' performance was within this band. Prior to the grading session, the assessors agreed that, if there would be a difference of more than $10 \%$ in the grading of each section, the three assessors would discuss the answers involved and consensus would be sought regarding the appropriateness of the grading and, if none was reached, an average mark would be given. However, discrepancies did not exceed $6 \%$.

The piloted group interview was semi-structured and involved five lecturers in the law faculty who were teaching first-year law students. The interview sought to determine the lecturers' expectations regarding the linguistic skills expected from their students. Triangulation was employed to ensure that the analysis of the data was valid, and a possible syllabus was designed on the basis of the findings. 


\section{RESULTS AND DISCUSSION}

\subsection{The questionnaire}

The questionnaire indicated that $96,5 \%$ of the participants mostly spoke Setswana at home and that these students' exposure to English mainly occurred when they were in class or when they were reading their academic texts. Eighty-eight percent of the participants were from the townships, rural villages and the informal settlements of the Mafikeng/Mmabatho area where they often had very little reading material, and sometimes no electricity or running water. The rest $(12 \%)$ came from the suburbs of the Mafikeng/Mmabatho area and other suburban areas and villages in the country and from outside the country. The average age of the participants was 19,7 years. Resident students comprised $48 \%$ of the participants and $52 \%$ commuted from home to the campus and back every school day. Ninety-eight percent of the participants had taken English as a first additional subject in grade twelve and their average symbol in it was an E. (This average symbol includes the scores of the students from other parts of Africa, which the South African Qualification Authority (SAQA) had comparatively converted into a local grading). Only $27 \%$ of the participants had a parent who had attained a post-secondary school qualification. Seventy-eight percent were dependent on either a bursary or a loan. Most of those who were not $(66 \%)$, said they often lacked money for food, learning materials, accommodation and tuition. Some had parents who could pay only the minimum amount the university required for them to register in the hope that they (the students) would later obtain a bursary or a loan. Some participants had siblings who were at school, which put a big responsibility on them to finish their studies as soon as possible so that they could help pay for their siblings' schooling. These students also were often plagued by guilt because had they been working, they would be helping their families to meet their financial needs. Sixty-six percent of the participants indicated that they did not think they needed EAS. Of that percentage, $78 \%$ said they took the course because of programme requirements and $22 \%$ said it was because of bursary requirements. Most of the students $(91 \%)$ said they would prefer the English remedial course to be content based and $73 \%$ said they would like to have a person from the law faculty who was also a language specialist as their lecturer.

The self-assessment section in the questionnaire required the participants to indicate how good they thought they were at the four major language skills, i.e. listening, speaking, reading and writing. Figure 2, below, indicates that, while participants, on the one hand, ranked their speaking proficiency low (35\%) (and to a lesser extent also their listening skill (48\%)), comparison of their self-assessments with the scores in the proficiency test for reading and writing, on the other hand, indicates that they overrated their reading ability (70\%) and their writing competence $(78 \%)$ by $22 \%$ and $35 \%$, respectively. 


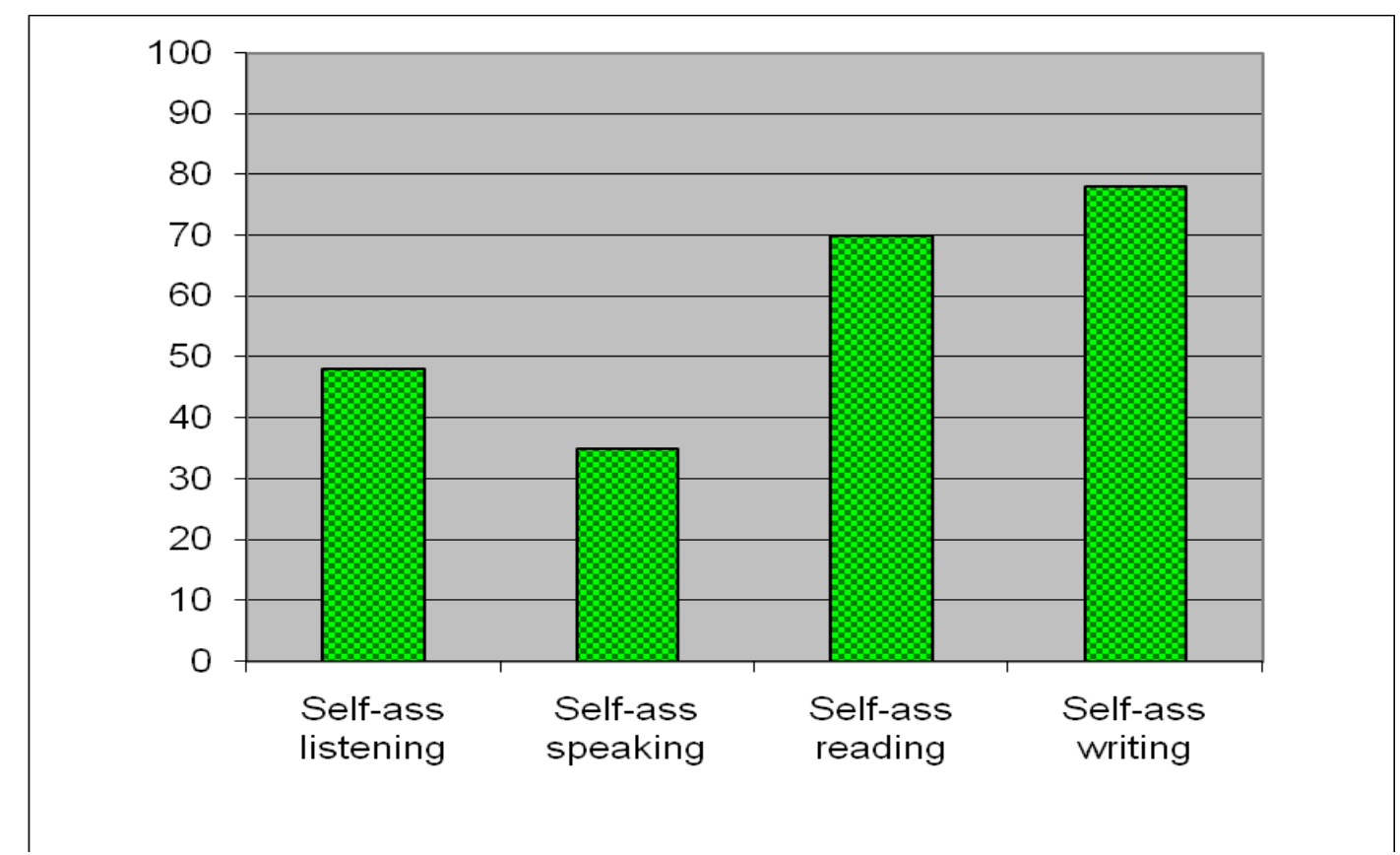

Figure 2: Self-assessment scores

As far as listening skill is concerned, Buthelezi (1984:12) notes that many South African ESL students at university may struggle to follow what the speaker says when exposed to people with unfamiliar accents for the first time, but sooner or later they tune in to the speaker's accent and this problem virtually disappears. With regard to speaking, reading and writing, Murray and Johanson (1990:17) point out that black students tend to underestimate their fairly good speaking skills. In contrast to this, they tend to overrate their reading and writing skills (Murray \& Johanson, 1989:147, 155). These trends are indicated in Figure 3 below.

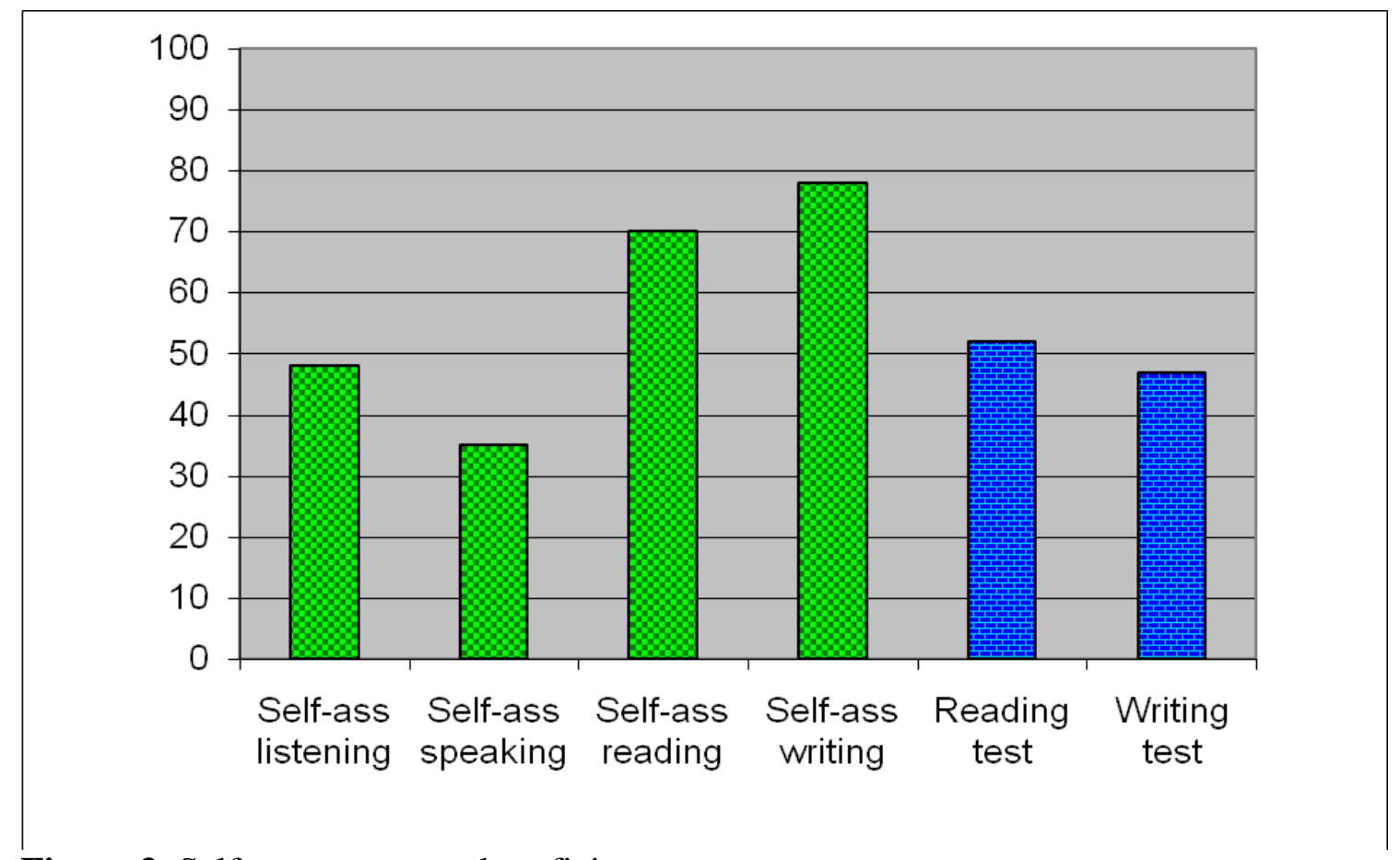

Figure 3: Self-assessment and proficiency test scores 
The disadvantages that the participants face are too numerous for many of them to learn as successfully as their white counterparts do. Firstly, their exposure to the language, which is so important for practising using the target language, is too little and their grade twelve average symbol in English too low. Secondly, the participants often experience financial difficulties that impact negatively on their studies. Although the Department of Education has been giving loans to a number of students through the National Students' Financial Aid Scheme (NSFAS), many needy students do not qualify to get this help. Getting a bursary or a loan usually requires a student to have a good academic track record and many poor students, like the participants in the current study, often do not have such. When needy students who have obtained good marks apply for financial assistance, they sometimes may be granted a loan or a bursary too late. This has resulted in complaints about universities' inability to manage and disburse money allocated to them. Dibetle (2008:2) reports that 'A total of R50 million allocated by the government to universities for loans to poor students went unused last year'. This disclosure came after continuing nationwide student protests (mostly by black students) against financial exclusions and escalating university fees. A constant criticism by students on black campuses, however, is that students' representative councils in these institutions often throw big 'bashes' (parties) and in many cases spend a great deal of the money they receive from NSFAS on buying liquor and other luxuries like designer clothes and expensive cellular telephones. While this might be true of some students, the plight of the majority of needy students is a genuine one. Inability to pay fees, purchase books and other learning and support resources, and psychological problems including lack of concentration are challenges many African students face. Often, one of the results of these factors is the constant threat of failing and the consequent expulsion, which impacts negatively on a student's studies and wellbeing.

The participants' prior learning and teaching processes were likely to have been teachercentred, as is often the case in many black rural schools. Despite the OBE promise to change this reality, many of the participants in the present study could not have had sufficient opportunities to converse in English in class. And although English was the official medium of instruction in the participants' schools, the vernacular, which was not the official medium of instruction, was often the de facto language of instruction. Exacerbating this problem is that many black learners, as Balfour (2007:11) observes, only achieve 'semilingualism' (not sufficiently literate in the L1 nor in the L2 being used as LoLT). Balfour (2007:11) also notes that 'many teachers (and adults in general) are functionally illiterate in English' in many black South African communities. Such teachers and adults are unlikely to want to be involved in conversations in which English is used, because doing so might expose their incompetence in the language and make them lose face.

With regard to reading and writing, pedagogy has not changed much from what it was about two decades ago (cf. Buthelezi, 1984:46) in many black schools. The little reading that learners are required to do in a few comprehension tests often comprises one short passage per test and most of their writing tasks normally consist of no more than manipulating various English structures. This could account for the participants' overrating of their ability in these skills; they must have assumed that the demands of reading and writing at university were the same as those at high school. That, perhaps, may also explain why the majority of the students indicated that they did not need to take EAS.

\subsection{Proficiency test results}

Unlike the self-assessment section in the questionnaire, which sought to establish the 
participants' perceived competencies in listening, speaking, reading and writing, the proficiency test was based only on reading and writing.

\subsubsection{Reading}

As Figure 3, above, indicates, the participants' average score in the reading comprehension test was $48 \%$. The average mark on decoding endophoric information was $58 \%$, and $37 \%$ on decoding exophoric information. Endophoric decoding required students to read a text and respond to questions for which answers were retrievable from the text. Because the participants' prior learning had been poor, many of the participants lacked basic skills, like correctly answering a true-or-false question, distinguishing between fact or opinion, skimming and scanning, understanding words in context, and recognising relationships between words, between sentences and between one paragraph and another. These skills are very important in the study of law because students have to refer to relevant cases now and then and construct cogent arguments based on facts and not on opinion and supposition. They also have to understand the use of words in various contexts and see how elements of a case cohere.

The question in the exophoric section required students to think conceptually, infer meaning, and be critical and they fared worse in it than in the endophoric section. One of the causes of the reading problems experienced by many students frequently is the assumption that all the answers to the questions they are asked are retrievable from the text. This assumption ignores the fact that meaning is often inferred from the context and constructed in the mind. In other words, readers, as they decode information on the printed page, need to activate their schema, make and check their predictions, and critique the text, and thus become more of top-down rather than bottom-up processors of information. If readers have a different linguistic and cultural background from the author's, this may offer a good opportunity to make an interesting contribution to the interpretation of a text. Sometimes they may have to work harder to comprehend the text, than readers from the same background as the writer's. This in itself can help them become more critical and reflective readers. It is necessary, therefore, for readers to critically evaluate their existing knowledge, attitudes and values and the writer's in the light of what they read. Adopting a critical reading stance is important for the participants, because, to defend a client in law, the lawyer (the major profession for which the participants are being prepared) has to punch holes in the other party's argument.

Academic reading is mostly a higher-level cognitive skill essential for success at university. As mentioned above, general proficiency in language is not a reliable predictor of a learner's academic success. It often is the learner who has been exposed to an environment that is rich with print material (which develops academic skills such as reading), who can make predictions about and infer meaning from legal texts more easily. The participants' reading problem was caused mainly by the impoverished background discussed above, with its lack of print-rich material. This disadvantage makes many of the participants in this study less aware of how their discipline 'languages' content in terms of genre than they would be in an environment with sufficient print material.

These poor results correlate with the low scores first-year students at the Mafikeng campus obtained in a standardised Test of Academic Language Literacy (TALL), which contrast sharply with those of their counterparts at the Potchefstroom campus, whose background fosters successful learning, as shown in Figure 4, below. 


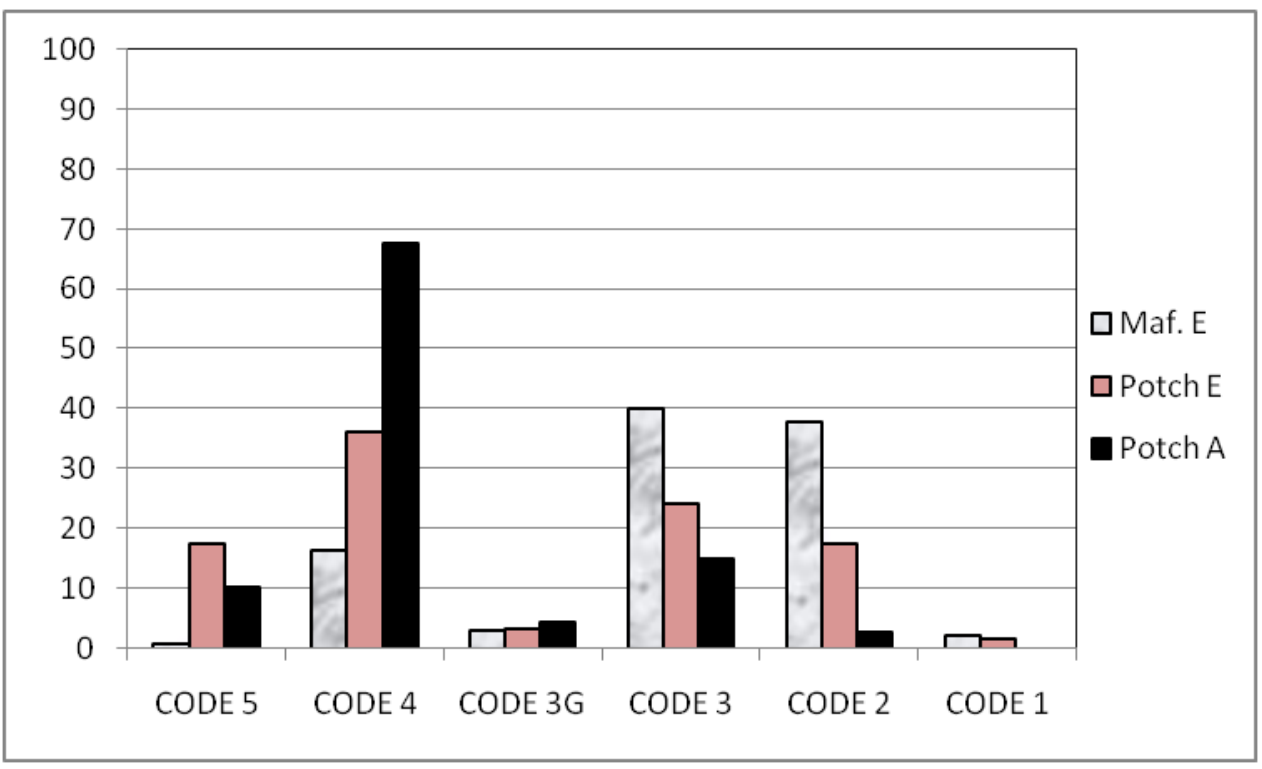

Figure 4: TALL scores from the Mafikeng campus and the Potchefstroom campus

"Maf E" in Figure 4 represents the Mafikeng ESL and the achievement of 708 English second language students who took the TALL in English. "Potch E" represents the Potchefstroom campus with its 265 students who were classified as English speaking. In reality, however, only a small minority of these were L1 English speakers, the majority being ESL learners who took TALL in English. "Potch A" represents Potchefstroom Afrikaans, referring to the 2951 Afrikaans L1 first-year students of the Potchefstroom campus who took the test in Afrikaans.

CODE 5 to CODE 1 indicate the highest to the lowest scores in TALL:

$\begin{array}{lrl}\text { CODE 5: } & 71-100 \% & \text { (no risk) } \\ \text { CODE 4: } & 43-70 \% & \text { (less risk) } \\ \text { CODE 3G: } & 41-42 \% & \text { (borderline cases) } \\ \text { CODE 3: } & 29-40 \% & \text { (at risk) } \\ \text { CODE 2: } & 14-28 \% & \text { (at high risk) } \\ \text { CODE 1: } & 0-13 \% & \text { (at the highest risk) }\end{array}$

Figure 4 therefore indicates that, in the CODE 5 band, only $.08 \%$ of the Maf E students obtained between 71-100\% while for Potch E students who fell within that range the percentage was $17.62 \%$, and for Potch A $0.27 \%$. Only $16.24 \%$ of the Maf E students appear in the CODE 4 band, while $36.23 \%$ of the Potch E, and a huge $67.58 \%$ of the Potch A students are represented here. Percentages for borderline cases were not that different: $2.97 \%$ for Maf E, 3.4\% for Potch E and 4.54\% for Potch A. Another big discrepancy is seen in CODES 3, 2 and 1, which represent students who failed. Mafikeng had a huge 79.94\% (combined) of failures, Potch E 43.02\% (combined), and Potch A only 17.66\% (combined).

The highest mark (17.62\% from Potch E) could be attributable to the fact that most of the students who obtained the highest marks were English L1 speakers who took the test in English. The highest failure rate (of Maf E) mainly resulted from the fact that these students used a foreign language as their LoLT and their background environment was not academically enabling. This result contrasts sharply with the high average score that Potch A 
students obtained, largely because they received mother tongue instruction, their living and learning environment was literacy-rich, and they took the test in their mother tongue Afrikaans. The failure rate of Potch $\mathrm{E}$ is higher than that of Potch A because the majority of the students in Potch E were not actually English mother tongue speakers, but ESL speakers who had been taught in second language and took the test in that language.

\subsubsection{Writing}

As Figure 3 shows, the average mark obtained by participants was $43 \%$ in the essay writing section. The essays displayed weaknesses in synthesising information from different texts; cohesion and coherence; writing critically; applying correct grammar; choosing an appropriate style; and employing correct spelling and punctuation. These weaknesses could be attributed largely to the students' lack of CALP skills. What has been said about how the scarcity of print materials and lack of the culture of reading in the participants' past environment led to their poor reading skills is true of their writing competency, too. The results of the proficiency test indicate, however, that the participants found writing more difficult than reading.

Another writing problem experienced by many African students is that these students often find it difficult to relate what they are learning to their lived experience because most of their curricula are Western-oriented. Their unfamiliarity with Western culture frequently leads to viewing their subject matter as ethereal, which is why some black first-year students sometimes write things that are senseless, even to themselves, but hope the lecturer will understand. Requiring students to write on something they do not understand well denies them the opportunity to make their voice heard. It also diminishes students' ability to articulate their internally understood cohesion and coherence and frequently results in students' abandoning their sense of planning. Product-oriented writing, which is what these students appear to have been instructed in, gives feedback but rarely requires them to revise their drafts; it short-circuits the long, arduous process of academic writing. Product-oriented writing only expects students to communicate what they already know, instead of allowing them to use writing as a tool for exploring and creating meaning. Widdowson (1980:235) criticises the tendency to regard writing merely as a means of communication, and argues for using it 'for thinking, for forming concepts and fashioning propositions' as well. Radloff (1994:12) suggests the presence of an important link between writing and learning when he remarks that 'Writing organises and clarifies our thoughts. Writing is how we think our way into a subject and make it our own. Writing enables us to find out what we knew - and what we don't know - about whatever we're trying to learn'. But besides making the participants aware of the cyclical nature of the writing process, they also need to be made aware of the discourse patterns of their discipline.

\subsubsection{Lecturers' group interview}

Five lecturers from the law faculty who were teaching the participants were interviewed as a group. Three of them said they would prefer the remedial English course that first-year law students were taking to be linked to a law subject or two in order to avoid the problem of skills transfer that usually occurs when the students' remedial course is only a general English course. The other two felt that trying to offer a genre-related course would not be practicable, because it would require English lecturers to liaise with law lecturers frequently, and neither of them had the time for that. What would work for them, they added, would be for English lecturers to ensure that they taught basic general English as well as possible so that the current 
language problems manifested by first-year students would be minimal. When asked if they would like to include the development of students' language skills in their teaching, all the lecturers said that, besides the fact that they already had a great deal of content to teach, they were not qualified to teach language. They were, however, concerned about the linguistic deficiencies revealed by first-years, especially in high-stake competencies such as reading and writing.

\subsubsection{Reading}

The law lecturers indicated that the students had to read at least twelve prescribed books and a large number of cases for the six courses first-years were taking. Recommended reading included reference books, articles from law journals, magazines and newspapers. The reading problems that first-years manifested, according to the lecturers, lay mostly in the areas of extracting facts from a text, following an argument, separating fact from opinion, separating main ideas from supporting details, and understanding relationships among various legal texts.

Legal texts are probably the most closed texts and poetry the most open. Smuts (2000:17) notes that 'The language of law is characteristically declaratory. This restriction to exposition and injunction means that whole areas of the potential of language, those of ambiguity, of tone, and the suggestiveness of symbol and metaphor, could safely be overlooked'. Students from a disadvantaged background, however, often lack basic decoding skills, due to having insufficient knowledge of the code used for learning and teaching. Students from a print-poor background usually have insufficient knowledge of the conventions of the printed word. What exacerbates their problem, as found in the current study, is that legal discourse is complex. According to Kilfoil (1997:iv), students of law frequently have to deal with:

- analysing sentences that can run into hundreds of words without adequate punctuation,

- wade through archaic language, inverted sentence structures, legal (often not English) jargon, cross references, and

- trying to link subjects to verbs and verbs to objects when they are separated by reams of redundant words.

One of the solutions for this would be to emphasise bottom-up processing initially, in which, in the words of Lightbown and Spada (2006:148), 'learners are put in situations where they cannot comprehend a sentence by depending solely on context, prior knowledge or other clues. Rather they must focus on the language itself'.

\subsubsection{Writing}

As far as writing in the first-year law programme is concerned, the three main writing tasks that students are required to carry out are, according to the lecturers interviewed, legal reporting, synthesising cases, and writing research papers aimed at giving students a good knowledge of how language skills operate in law. Writing legal reports is mainly concerned with identifying the relevant parts of a case and writing them in a clear, concise, and coherent briefing for presentation in a hypothetical court. In synthesising cases, students identify similarities and differences in a number of cases, paying particular attention to instances in which similar facts lead to different outcomes in some legal cases. Report writing and synthesising information provide students with a solid foundation for a more difficult writing task - writing a research paper. 
The law lecturers also indicated that the writing problems revealed by many first-year students were those that involved synthesising information; writing critically (to sound one's voice); taking one's own stance and using authoritative sources only to support one's case; applying cohesion and coherence, an appropriate style, good grammar, extensive vocabulary, and correct punctuation and spelling; and avoiding plagiarism. Asked if their teaching and assessment allowed for any form of multimodal expression of meaning, given that text is made in other artefacts besides language, the interviewees said that lack of training, and time constraints, made them use the linguistic mode exclusively.

Kilfoil and Van der Walt (1997:248) mention three types of writing. The first is manipulation, done when one learns to write the orthography of a foreign language like a Mandarin script. The second is structuring, which is about the formulation of sentences and sometimes paragraphs in the target language. Most of the writing tasks in many black schools scarcely go beyond the sentence level. They are rarely, in other words, focused on extended writing through which students explore and create meaning. The third stage is a context-reduced and cognitively demanding one, requiring students to explore, create, and critique meaning in order to communicate. The participants need to be well equipped with these types of skills because they feature prominently in argumentative writing, which universities prize very highly.

\section{A GENRE-BASED APPROACH TO READING AND WRITING}

The participants' difficulty in understanding the legal genre they are dealing with could best be remedied when students are helped to become part of an academic discourse community through making them aware how different texts are structured in unique and noticeable ways according to their purpose, audience and message. What a syllabus like the one proposed in the current study would do, in this regard, would be to provide content for raising students' meta-cognition of their subject matter. Once students are aware of the rhetoric of their discipline, their acquisition of the mechanical aspects of reading and writing - explicit meaning, cohesion, style, vocabulary, grammar, punctuation and spelling - are likely to be more easily acquired. This does not, however, mean blind conformity: students would also acquire the capacity to criticise the values, attitudes and practices underlying their learning and teaching processes. It is opportunities such as these that would give L2 students the right to legitimate their academic credentials and to effectively participate as group members of academia. The content would focus on the teaching of reading and writing.

Reading and writing entail cognitively demanding skills for law students. In terms of reading, Feak and Reinhart (2002:12) point out that 'General academic reading strategies do not translate into good case reading strategies because of the distinctive characteristic of a case or court opinion, such as its structure'. Meta-discourse here, according to Bhatia (1993: 135136), entails an awareness of four moves, i.e.

- identifying the contextual details such as the publisher, the court, the court's date and the judge who wrote the opinion,

- establishing the facts of the case,

- arguing the case,

(a) stating the history of the case,

(b) presenting the argument, 
(c) deriving the ratio decidendi (a legal principle), and

- pronouncing judgment or verdict.

Furthermore, students need to acquire the skill to handle more than one case in a sophisticated manner. According to Feak and Reinhart (2002:13), students need to apply the following reading processes:

- making connections among a series of related cases in a particular field of law,

- drawing conclusions from the thread identified above,

- anticipating how the thread may continue,

- using a principle to critique a court's judgment, and

- applying a principle to a hypothetical situation.

With regard to genre-based writing, Feak and Reinhart remark (2000:13-14) that writing a research paper demands that students possess the following competencies:

- accessing information on line, from the library (law library), from the media, and from other sources,

- awareness and use of the meta-discourse for presenting a research paper (e.g. use of the problem-solution information structure),

- using legal language (qualification of claims, reporting verbs, and key concepts), and

- using referencing conventions of published legal texts.

Many of first-year law students, including the participants in this study, lack these skills.

While plagiarism is unacceptable, it should be borne in mind that some students may plagiarise unwittingly. They may, as Angelil-Carter (2000) points out, not be after using the idea of a source but the expression, so that what they write conforms to protocol. What this means, in effect, is that, while they may be attempting to meet one requirement, they, at the same time, are violating another. In addition, novice writers sometimes have a problem with expressing their own ideas which might be accidentally contained in a source they are using. Phrase such as 'As $\mathrm{X}$ rightly argues,...', ' $\mathrm{Z}$ is instructive when he notes...' 'In the words of $Y, \ldots$ ' can help such students to express their ideas and those of an authoritative source simultaneously.

In the case of L2 students' tendency to fail to state the case they want to argue and only use an authoritative source to support this in a conventional way, Hyland (2003:20) observes that this problem might present a big challenge in an L2 environment, because '[ $\mathrm{k}]$ ey principles which originated in [an] L1 classroom such as personal voice, peer review, critical thinking, and textual ownership tacitly incorporate an ideology of individualism which L2 students may have serious trouble accessing'. What this challenge might require is that the lecturer recognise and affirm instead of condemn the rhetorical patterns the ESL student is familiar with and utilise these as a basis for the learner to acquire the requisite academic discourse patterns. Because taking into account both the students' background and the target competency aimed for are crucial in teaching legal academic discourse, it could be safely concluded that while the process writing models have contributed a great deal towards our understanding of writing by shifting focus from the solely formal product models to the psycho-cognitive processes of composing, they have, however, failed to take into consideration the socio-political factors of the L2 students' backgrounds, particularly the values, goals and practices of the student's learning institution. What this suggests is the use of the genre approach as a means for equipping students with the most effective capacity to 
both access and critique cultural and linguistic resources of their target learning and teaching environment (Hyland, 2003:25).

The genre approach could also exploit the use of multimodal literacy, especially in dealing with students who mainly have an oral background, like the participants in this study have. Multimodal literacy could include 'live performances, the aesthetics of the body, music, image and multilingualism' (Stein \& Newfield, 2006:2) as a way of complementing or accessing the code of legal discourse. Stein and Newfield's (2006) argument for this is that text is not made up exclusively of language, thus implying that, while lecturers should do what they can to enable students to meet the current requirements of academic literacy, they should take cognizance of the role of other marginalised text types, like the ones just mentioned, because students' culture, language and identity contribute a great deal towards their academic success.

Regarding collaboration between law and language lecturers to address the problems discussed above, the success of a remedial English course would be dependent on the degree to which the two work together. Collaboration could take the following form: At the beginning of a semester the language and law lecturers could meet for a few days (about four or five) and work out the outcomes of a content-based course, the basic content, and basic materials assessment criteria to use. The language teacher would then work out the details and implement the course. At the end of the course, the language lecturers could again meet for about four to five days to evaluate the course. The course would be modified on the basis of the evaluation, and the cycle would begin again.

\subsection{A proposed course}

Although the proposed genre-based course puts emphasis on the teaching of reading and writing, the study presupposes the use of an integrated communicative cyclical approach, which would take care of developing listening and speaking skills. In order to complement the development of the students' reading and writing skills, the course assumes the inclusion of explorations of multimodal literacy and sociocultural issues that go together with language use. Explaining the subject matter may be undertaken, but emphasis should be (placed) on engaging students in cognitively stimulating tasks conducted individually and in groups. The tried and tested method of teaching from the familiar to the unfamiliar and from the simple to the complex is recommended.

Although there are a number of texts that can be used for the proposed syllabus, locally produced material should be given preference over overseas texts. Working with students like the participants in the current study is often more effective if the main texts used are drawn from their immediate environment, because this tends to increase their confidence and creative ability, which in turn makes them think more analytically and critically. Besides this, such texts are cheaper and more easily accessible than imported material. A text written by a local language specialist in collaboration with a law lecturer, for instance like English for Law Students by C Van der Walt and AG Nienaber (1997, Kenwyn: Juta) would, therefore, be highly recommended as a prescribed book for first-year law students at the NWU, Mafikeng campus. Among other things, the book explains and teaches (within the legal genre) study skills, reading and writing, vocabulary, problematic language areas, test and examination techniques. Supplementary texts might include the following: 
- A Dictionary of Modern Legal English Usage. $2^{\text {nd }}$ Edition. Oxford: Oxford University Press.

- Finch, E. and Fafinski, S. 2009. Legal Skill. Oxford: Oxford University Press.

- Gardner, BA. 2001. Legal Writing in Plain English: A text with exercises. (Chicago guides to writing, editing, and publishing). Chicago: Chicago University Press.

- Krois-Lindner, A. 2006. International Legal English Student's Book with Audio $C D s$ (suitable for the International Legal English Certificate - ILEC). $1^{\text {st }}$ Edition. Cambridge: Cambridge University Press.

- Krois-Lindner, A and M Firth. 2009. Introduction to International Legal English. Student's book with audio CDs: A course for classroom or self-study use. Cambridge: Cambridge University Press.

- Riley, D. 2006. Check your English Vocabulary for Law. All you need to improve your vocabulary. New York: A \& C Black Publishers Ltd.

The following remedial English course content for first-year law students is proposed on the basis of the above.

\subsubsection{Reading}

\begin{tabular}{|l|l|}
\hline $\begin{array}{l}\text { Lower-level } \\
\text { skills }\end{array}$ & $\begin{array}{l}\text { Identifying direct reference; finding a copy item; decoding derivation and } \\
\text { sentences, and decoding meaning conveyed through punctuation and } \\
\text { spelling. }\end{array}$ \\
\hline $\begin{array}{l}\text { Higher-level } \\
\text { skills }\end{array}$ & $\begin{array}{l}\text { Understanding meaning in context; distinguishing fact from opinion; } \\
\text { understanding meaning not immediately obvious; understanding meaning } \\
\text { in context; relating one part of a passage to another; understanding non- } \\
\text { linear information; understanding register and different levels of } \\
\text { formality; understanding legal discourse; critically relating endophoric } \\
\text { information to exophoric information; synthesising information from } \\
\text { various texts; applying given or known knowledge to carry out a complex } \\
\text { reading task; evaluating a text using a particular yardstick; distinguishing } \\
\text { main ideas from supporting details; making predictions; relating linear } \\
\text { information to non-linear information; and understanding the meta- } \\
\text { discourse of legal English. }\end{array}$ \\
\hline
\end{tabular}

\subsubsection{Writing}

\begin{tabular}{|l|l|}
\hline $\begin{array}{l}\text { Low- } \\
\text { level } \\
\text { skills }\end{array}$ & $\begin{array}{l}\text { Writing and paraphrasing sentences in context; constructing structured writing } \\
\text { (reporting cases); constructing guided writing (reporting cases); engaging in } \\
\text { multimodal literacy; editing for spelling, punctuation and grammar; and using } \\
\text { referencing techniques. }\end{array}$ \\
\hline $\begin{array}{l}\text { High- } \\
\text { level } \\
\text { skills }\end{array}$ & $\begin{array}{l}\text { Synthesising various cases; writing a research paper; establishing one's } \\
\text { purpose; brainstorming; gathering information; organising ideas and } \\
\text { information (meta-discourse); drafting (cohesion and coherence); revising; } \\
\text { editing for style. }\end{array}$ \\
\hline
\end{tabular}




\section{CONCLUSION}

Many students at historically black campuses like the Mafikeng campus of the North-West University are insufficiently prepared for university studies in terms of academic literacy. For first-year law students, the problem is exacerbated by the fact that these students have to contend with learning a foreign language and obscure legal discourse before they can grapple with understanding content and acquiring the academic skills that go with it. One of the means of addressing this problem is to establish a thorough profile of these students and to link it to the kind of language and skills they are expected to have through the use of the genre approach. Besides lending face validity to the input and obviating the problem of transfer that usually arises when students take a general English remedial course, genre-based instruction raises students' awareness of the rhetoric of their discipline and makes learning easier. Because the students in question are drawn from a disadvantaged background, it would be necessary to emphasise the teaching of lower-level skills first before higher-level skills. It would be necessary to emphasise the teaching of lower-level skills before higher-level skill are taught. For reading, decoding derivation and sentences as well as understanding meaning conveyed through punctuation and spelling could be taught more than teaching synthesising information and critical reading initially, for instance. This emphasis could be reversed later. For writing, structured and guided writing could be taught thoroughly first before unguided is taught. in the language areas on which their success or failure depends i.e. reading and writing. To broaden the input, the inclusion of multimodal literacy and sociocultural issues, especially ideology in language use, which has been shown to be an intrinsic part of academic literacy, could be included. By 'nuancing' academic literacy in this way, the proposed remedial course will debunk the fallacy that teaching academic literacy is an abstract and decontextualised practice, and that ESL students' language problems are caused by their own failure to learn and EAP consequently should be focused on simply eliminating general language problems.

\section{REFERENCES}

ALIDOU, H. 2003. Language policies and language education in Francophone Africa: A critique and a call to action. In Makoni, S, G Smitherman, A Ball \& A Spears. (Eds), Black Linguistics: Language, society and politics in Africa and the Americas. London \& New York: Routledge.

AGAR, D. 1990. The SPEN Report. University of Bophuthatswana. Mafikeng.

ANGELIL-CARTER, S. 2000. Understanding plagiarism differently. In Leibowitz, B \& Y Mohamed (Eds), Routes to writing in Southern Africa. Cape Town: Silk Road International.

ASMARA DECLARATION, 2000. Against all odds: African languages and literature into the $21^{\text {st }}$ century. [Online]. Available: http://www.outreach.psu.edu/C\&I/AllOdds/declaration.html [2009, 19 June].

BALFOUR, RJ. 2007. Mother-tongue education or bilingual education for South Africa: theories, pedagogies and sustainability. Journal for language teaching, 41(2):1-14.

BALL, A. 2003. US and South African teachers' developing perspectives on language and literacy: Changing domestic and international roles of linguistic gate-keepers. In Makoni, S, G Smitherman, A Ball \& A Spears (Eds), Black Linguistics: Language, society and politics in Africa and the Americas. London \& New York: Routledge. 
BALL, A \& T LARDNER. 2005. African American Literacies Unleashed: Vernacular English and the composition classroom. Carbondale: Southern Illinois University Press.

BALL, A \& S FREEDMAN (Eds), 2004. Bhaktinian Perspectives on Language, Literacy and Learning. Cambridge: Cambridge University Press.

BHATIA, VK. 1993. Analysing genre: Language use in professional settings. London: Longman.

BRINTON, DM, MA SNOW \& M WESCHE. 2003. Content-based second language instruction: Michigan Classics (Revised edition). New York: Newbury House.

BROWN, HD. 2000. Principles of language learning and teaching ( $4^{\text {th }}$ edition). New York: Longman.

BUTHELEZI, Q. 1984. The communicative needs of first-year black Social Work students. ASPect 5. A selection of papers and workshop items presented at the ASP Workshop held at the University of Cape Town, 4-6 December.

CELCI-MURCIA, M (Ed). 2001. Teaching English as a second or foreign language ( $3^{\text {rd }}$ edition). Boston, MA: Heinle \& Heinle.

CITY PRESS. 2008. 29 June:12.

CONSTITUTION OF THE REPUBLIC OF SOUTH AFRICA, ACT 108 of 1996.

DANET, B. 1985. Legal Discourse. In Van Dyk, TA (Ed), Handbook of discourse analysis. London, New York, \& Sydney: Academic Press.

DENZIN, NK \& YS LINCOLN. 2000. Introduction: the discipline and practice of qualitative research. In Denzin NK \& YS Lincoln (Eds), Handbook of qualitative research $\left(2^{\text {nd }}\right.$ edition). Thousand Oaks, London \& New Delhi: Sage. 1-28.

DEPARTMENT OF EDUCATION. 1995. White paper on education and training. Pretoria: Government printers.

DEPARTMENT OF EDUCATION. 1996. The national commission on higher education report. Pretoria: Government printers.

DEPARTMENT OF EDUCATION. 2002. Language policy framework for South African higher education. Pretoria: Government printers.

DIBETLE, M. 2008. Fury over unspent millions. Mail \& Guardian, 28 March to 3 April:2.

DUENAS, M. 2004. The whats, whys, hows and whos of content based instruction in second/foreign language education. International journal of English studies, 4(4):73-96.

ELLIS, R \& G BARKHUIZEN. 2005. Analysing learner language. Oxford: Oxford University Press.

FEAK, C \& S REINHART. 2002. An ESP program for students of law. In Orr, T. English for specific purposes: case studies in TESOL practice series. Alexandria, Virginia: Teachers of English to Speakers of other Languages, Inc. (TESOL).

GASS, S. 1997. Input, interaction, and the second language learner. Mahwah, NJ: Lawrence Erlbaum.

HALL, JK. 1997. A consideration of SLA as a theory of practice. Modern language journal, 81:301-306.

HYLAND, K \& L HAMP-LYONS. 2002. EAP: Issues and directions. Journal of English for academic purposes, 1:1-12. 
HYLAND, K. 2003. Genre-based pedagogies: a social response to process. Journal of second language writing, 12:17-29.

KILFOIL, WR \& C VAN DER WALT. 1997. Learn 2 teach $\left(3^{\text {rd }}\right.$ revised edition). Pretoria: Van Schaik.

KILFOIL, WR. 1997. Study guide for Pen 100-3. English communication for law. Pretoria: University of South Africa.

KLEIN, D \& F VILJOEN. 1995. Beginner's guide for law students. Cape Town: Juta.

KUMARAVADIVELU，B. 1994. The postmethod condition: (E)merging strategies for second/foreign language teaching. TESOL Quarterly, 28(1):27-48.

LANTOLF, J \& G APPEL (Eds). 1994. Vygotskyan approaches to second language research. Norwood, New York: Ablex.

LARSEN-FREEMAN, D. 2000. Second language acquisition and applied linguistics. Annual Review of Applied Linguistics, 20:165-181.

LIGHTBOWN, PM \& N SPADA. 2006. How languages are learned ( $3^{\text {rd }}$ edition). Oxford: Oxford University Press.

LONG, ML. 1983. Does second language instruction make a difference? A review of research. TESOL Quarterly, 28 (1):27-57.

LONG, ML. 1996. The role of linguistic environment in second language acquisition. In Ritchie, W \& T Bhatia (Eds), Handbook of second language acquisition. New York: Academic Press.

MELLINKOFF, D. 1963. The language of law. Boston: Little Brown.

MURRAY, S \& L JOHANSON. 1989. Read to learn. Bergvlei: Hodder \& Stoughton.

MURRAY, S \& L JOHANSON. 1990. Write to learn. Bergvlei: Hodder \& Stoughton.

NUNAN, D. 2003. Practical English language teaching. London: McGraw Hill.

ORGANISATION OF AFRICAN UNITY. 1986. Language plan of action for Africa. [Online]. Available: http://www.bisharat.net/Documents/OAU-LPA-86.htm [2009, 19 June].

PAN SOUTH AFRICAN LANGUAGE BOARD, Act No. 59 of 1995. Pretoria: Government printers.

RADLOFF, A. 1994. Writing to learn, learning to write: helping academic staff to support students writing in their disciples. Unpublished paper presented at the thirteenth international conference on staff and educational development at the University of Cape Town. Cape Town, 15-18 June.

RAMPHELE, M. 2009a. Another generation betrayed. Sunday Times, 18 January:19.

RAMPHELE, M. 2009b: Here mother tongue clashes with her mother tongue. Sunday Times, 8 March:11.

RNCS (REVISED NATIONAL CURRICULUM STATEMENT). 2002. Department of Education, Pretoria: Government printers.

RILEY, A. 1994. English for law. Ismaning: Max Hueber.

SA FM Morning Talk. Wednesday 28 January 2008. 
SMUTS, J. 2000. The design and effectiveness of the course English for LLB students at the University of Free State. Proceedings of the conference of the Association of University English Teachers of South Africa (AUETSA) held at North-West University, Potchefstroom, 18-20 November.

STEIN, P \& D NEWFIELD. 2006. Multiliteracies and multimodality in English education in Africa. English studies in Africa, 49(1):1-22.

UNITED NATIONS EDUCATIONAL, SCIENTIFIC AND CULTURAL ORGANISAITON (UNESCO). 1968. The use of vernacular languages in education. In Fishman, JA (Ed), Readings in the sociology of language. The Hague: Mouton. 688-716. Originally published in 1953.

VAN DER WALT, C. 1992. Teaching a foreign language: the language of the law. Tydskrif vir hedendaagse Romeins-Hollandse reg, 55(1):94-102.

VAN DER WALT, C \& AG NIENABER. 1997. English for law students. Cape Town: Juta.

WIDDOWSON, HG. 1980. Conceptual and communicative functions in written discourse. Applied Linguistics, 1(3):234-243.

WINFORD, D. 2003. Ideologies of language and socially realistic linguistics. In Makoni, S, G Smitherman, A Ball \& A Spears (Eds), Black linguistics: Language, society and politics in Africa and the Americas. London \& New York: Routledge.

WYDICK, R. 1994. Plain English for lawyers. Durham, North Carolina: Carolina Academic Press.

ZULU, C. 2005. Academic reading ability of first-year students: What's high school performance or prior learning exposure to academic reading got to do with it? Southern African linguistics and applied language studies, 23 (1):111-123.

ZULU, C. 2008. First-year university L2 readers' patterns of performance in a test of academic reading ability. Language matters, 38(2):2007:316-331.

\section{BIOGRAPHICAL NOTE}

The author has taught English second language at both high school and higher education level. His language areas of interest include language planning and policy; language varieties, especially South African Black English; and academic literacy. He is currently at the North-West University, Mafikeng campus, where he, among other classes, teaches first-year law students.

Email: ngwenyat@uniwest.ac.za 


\section{APPENDIX \\ QUESTIONNAIRE FOR FIRST-YEAR LAW STUDENTS}

The English and Academic Skills (EAS) course aims at meeting students' language needs as much as it possibly can through, among other things, making sure that the subject fulfils these needs. The purpose of this questionnaire is to involve you in achieving that purpose. Please fill it in. The information you provide will be confidential, so you should feel free to say exactly what you think about yourself, your language needs, and EAS. Your giving of information should not be influenced by a desire to say what you think your lecturer would like to hear. Please do NOT write your name. Where applicable, make a cross in the box provided and where there is a line, write the answer.

$1 \quad$ Your gender

\begin{tabular}{|l|l|l|l|}
\hline Male & & Female & \\
\hline
\end{tabular}

2 Indicate what your parents' or guardians' highest educational level is:

\begin{tabular}{|l|l|l|}
\hline$\underline{\text { Highest educational level }}$ & $\underline{\text { Father/father figure }}$ & Mother/mother figure \\
\hline below primary school certification & & \\
\hline primary school certification & & \\
\hline secondary school certification & & \\
\hline higher education certification & & \\
\hline
\end{tabular}

3 Your age ___ years

$4 \quad$ Where did you matriculate?

School

Town/city or village

Province

5 What is the language you speak most at home?

6 Indicate what type of student you are.

\section{resident} non-resident

$7 \quad$ Are you studying on a bursary or loan?

\begin{tabular}{|l|l|l|l|}
\hline Yes & & No & \\
\hline
\end{tabular}


8. At what level did you take the English grade twelve examination?

\begin{tabular}{|l|l|}
\hline English first language higher grade & \\
\hline English first language standard grade & \\
\hline English second language higher grade & \\
\hline English second language standard grade & \\
\hline
\end{tabular}

Other (please specify)

9. What symbol did you obtain in the English grade twelve examination?

10. What was the aggregate symbol you obtained in the grade twelve examination?

11. When do you use English?

\begin{tabular}{|l|l|l|l|l|l|l|l|}
\hline when studying & & when socialising & & at meetings & & at home & \\
\hline
\end{tabular}

Others (please specify)

12. Is this the first time you have taken EAS?

\begin{tabular}{|l|l|l|l|}
\hline Yes & & No & \\
\hline
\end{tabular}

If No, how many times have you taken it?

\begin{tabular}{|l|l|l|l|}
\hline Twice & & More than twice & \\
\hline
\end{tabular}

13. Do you think you, as a first-year student, needed a remedial English course like EAS?

\begin{tabular}{|l|l|l|l|}
\hline Yes & & No & \\
\hline
\end{tabular}

Give a reason for your answer

14. Why are you taking EAS?

\begin{tabular}{|l|l|}
\hline It seems easy to pass. & \\
\hline I was advised to take it. & \\
\hline I like studying languages. & \\
\hline I thought it would be helpful. & \\
\hline It is a programme requirement. & \\
\hline It is a bursary/loan requirement. & \\
\hline
\end{tabular}

Other reason (please specify) 
15. Indicate how good you are at the skills below, using 1 - 4 with 4 indicating your best ability.

\begin{tabular}{|l|l|}
\hline listening skill & \\
\hline speaking skill & \\
\hline reading skill & \\
\hline writing skill & \\
\hline
\end{tabular}

16. Whom do you regard as the best person to teach EAS?

\begin{tabular}{|l|l|}
\hline A law lecturer & \\
\hline A language specialist & \\
\hline A good post-graduate student assistant & \\
\hline A law lecturer who is also a language specialist & \\
\hline
\end{tabular}

17. Are there any non-academic problems you are experiencing at present?

\begin{tabular}{|l|l|l|l|}
\hline Yes & & No & \\
\hline
\end{tabular}

If so, mention the most important TWO.

18. Mention the ONE most important improvement you think should be made to EAS.

19. Mention any other improvement that could be made to EAS.

Thank you for filling in this questionnaire. 